https://helda.helsinki.fi

\title{
Perfections, Clarity, and Congruity
}

\section{Saarinen, Risto}

2019

Saarinen, R 2019 , ' Perfections, Clarity, and Congruity ', Pro Ecclesia : a journal of

Catholic and Evangelical theology. , vol. 28 , no. 2 , pp. 114-119 . https://doi.org/10.1177/1063851219842401

http://hdl.handle.net/10138/310406

https://doi.org/10.1177/1063851219842401

unspecified

acceptedVersion

Downloaded from Helda, University of Helsinki institutional repository.

This is an electronic reprint of the original article.

This reprint may differ from the original in pagination and typographic detail.

Please cite the original version. 


\title{
PERFECTIONS, CLARITY, AND CONGRUITY
}

\author{
John M. G. Barclay, Paul and the Gift (Grand Rapids: Eerdmans, 2015).
}

Reviewed by Risto Saarinen, University of Helsinki

John Barclay's Paul and the Gift is one of the most important theological books in recent years. In addition to being a professional and original study in exegetics, this monumental work can also be read as an intellectual history of the view of grace as gift in Christianity. The reader obtains, as superadded gifts, introductory courses in social anthropology and philosophy from Marcel Mauss to Jacques Derrida.

The first part of the book, "The Multiple Meanings of Gift and Grace" offers 200 pages before the author is ready to proceed into biblical exegetics. Barclay discusses the different perfections of grace and the gift in the Greco-Roman world and later Western culture extensively. He considers that the modern idea of "pure gift" is influenced by the Reformation and connected with Martin Luther's theology. This view is very close to Berndt Hamm's recent claims in Luther research. While Barclay does not quote Hamm, his knowledge of Reformation research is otherwise impressive.

The first part is very erudite in its interdisciplinary observations. Barclay is well informed of older and more recent sociological, anthropological, and philosophical studies. The most impressive discussion, however, concerns his own main innovation to the theological nature of grace or gift. With the help of the (surprisingly old) rhetorical maxims of Kenneth Burke, Barclay argues that one can reach definitional clarity through "perfecting" a concept, that is, through drawing it out to its endpoint or extreme. Barclay's own big innovative argument claims that, since gift-giving is a multifaceted phenomenon, the concepts of grace and gift can be perfected in multiple ways. (pp. 67-69).

Barclay drafts six different perfections of donative grace, that is, superabundance, singularity, priority, incongruity, efficacy and non-circularity. While each of them expresses a "pure" gift in its own specific manner, the six perfections are nevertheless conceptually distinct from one another. For instance, grace can be singular without having priority or efficacy. Grace can be superabundant without being incongruous or non-circular. Barclay wants to say to the philosophers that their quest after the "pure gift" needs to pay attention to the different perfections. More importantly, the six perfections serve for him as an exegetical tool which allows him to explain why and how some earlier Pauline scholarship on grace has gone wrong.

The second, third and fourth part of the volume present an extensive historical argument. The second part is devoted to "Divine Gift in Second Temple Judaism", the third part focuses on Galatians and the fourth part on Romans. Barclay shows in great detail how Paul's theology of grace and gift is best understood in terms of the incongruity of grace. While other perfections are also important, he claims that the incongruous grace unites the central themes of Pauline thinking (pp. 463, 561). Earlier scholarship has often confused this perfection with other perfections of grace or gift. 
Through his exegetical discussion, Barclay consistently assumes that charis can often be translated in terms of gift. In the last section of the book he offers an appendix "The Lexicon of Gift: Greek, Hebrew, Latin, and English". Here he pays some attention to the Greek verb didomi and nouns like dosis and dorema. His analysis of biblical writings is nevertheless strictly focused on charis. This procedure is on the one hand necessary, since the meaning of charis can be debated and one needs extensive grounds to claim that this word means "the gift" so strongly that even anthropological comparisons are necessary to understand biblical grace.

On the other hand, the title "Paul and the Gift" evokes the expectation that the verb didomi and its compounds would be discussed at some length. Already the older exegetical scholarship (e.g. Wiard Popkes, Christus traditus, 1962) has shown how rich theological meanings are build around the basic terminology of giving and the gift in earliest Christianity. While the discussion on charis is extremely important by its own right, the horizon of donative terms in the New Testament is much broader. To be sure, Barclay offers a broader spectrum of terminologies in his concrete exegesis, considering a huge range of different vocabularies regarding divine giving and human reception.

Generally speaking, I am very happy that contemporary biblical scholars take philosophical and conceptual matters seriously and allow comparisons with historical (Cicero, Seneca) and contemporary (Alain Badiou, Derrida) thinkers. I am particularly glad that Barclay employs Luther's theology and offers a reading which is close to many new publications in Luther studies (Hamm, Bo Holm and myself). In the new Luther-Handbuch ( $3^{\text {rd }}$ ed., 2017, p. 42) Volker Leppin says that "the most important theological debate of current Luther scholarship concerns the nature of the gift".

Not only Barclay's analysis of Paul but also his views on Augustine, Luther and Calvin contribute to this debate and deserve to be read by all Reformation scholars. I believe that Barclay is right in identifying the modern desire to define the so-called "pure gift". This concept emerges in the Reformation and finds different expressions in current philosophy and theology. I agree with Barclay that there is no one pure gift but several different versions or perfections of grace or gift in our thought world.

II

A truly important study invites the reader to make critical responses. As a systematic theologian I have two criticisms to present. My first criticism concerns the basic methodological view that a concept is best clarified when drawn to its extreme endpoint. Let me label this view as "Platonic", meaning that in knowing a concept we proceed from shadows to the ideal world where we finally meet the concept in its extreme clarity and perfection. The contemporary French debate on pure gift (Derrida, Jean-Luc Marion etc.) is Platonic in this sense. When Barclay proceeds from the textual shadows to the ideal perfection of the concept, he finds a plurality of perfections. After careful exegetical scrutiny, he claims that perfect "incongruity" is the most fitting Pauline idea of grace as gift.

Let me propose another methodology, namely, an "Aristotelian" one. In this method, the core meaning of the concept is something like a mean. The opposite extremes are important to know, but the truth and the virtue of the matter discussed are found between the extremes. Given this, a gift should, on the one hand, avoid commercial features. It cannot look like a bribe or a payment and it cannot be conditioned by strict expectations of return. On the other hand, the gift cannot be a merely anonymous and unilateral transfer of a thing, or an 
automaton which constructs and produces the reactions of its lethargic recipient. The true concept of the gift avoids both extremes.

The modern construction of unilateral pure gift (p. 63) exemplifies the Platonic method. The classical discussion of Seneca in De beneficiis as well as the modern anthropological studies proceed from an asymmetric reciprocity between givers and recipients, manifesting a more Aristotelian approach. Barclay holds that Paul's view of incongruous grace does not rule out circularity because the gift carries expectations of obedience (p. 569). Barclay's own methodology thus deals with the perfection of incongruity through moderating some other perfections of the gift. In this manner, his Platonic search is balanced with an Aristotelian attention of different perfections.

With the help of the Aristotelian conception we can also understand the world of giftgiving so that not the extreme perfections but the ordinary and everyday practices of gift exchange express the paradigmatic gift. This is the trend in studies like Zemon Davis, The Gift in Sixteenth-Century France (2000), Henaff, The Price of Truth (2002/2010) and Godbout, The World of the Gift (1992/1999). Many biblical stories of giving and receiving can be explained in such Aristotelian manner. A rich youngster needs to sell all his property, a poor widow gives one or two small coins, a ruler is given his due. None of these acts intends to be "pure" in the sense of an extreme, but they all express a mean which does not exhaust the resources of the giver. After these acts, the rich youngster still has more capabilities than the poor widow. While their acts of giving are all proper in their own context, they are not pure gifts in any modern sense of the term. It may nevertheless be adequate to call them perfections in some manner.

But what about grace? Can we also read Paul in an Aristotelian fashion, arguing that charis can express a proper mean rather than a particular perfection? The best affirmative answer to this question would be a thorough exegetical argument. I cannot produce it here but offer a systematic argument which proceeds from Barclay's view of Pauline grace as both incongruous and circular.

Seneca's famous example (De beneficiis 2,17 ) illustrates the incongruity between Antigonus and the cynic. When the cynic begs for a talent, Antigonus considers that this is more than a beggar can ask for. Then the cynic asks for a denarius. Antigonus replies that this is less than a king could becomingly give. Seneca goes on to remark that a continued circulation could solve the incongruity, as Antigonus could give a denarius, considering that every gift given out of kindness is proper. He could also remark that since cynics despise money they should not beg for it. Congruity can thus be found in spite of initial incongruity.

A theological analogy regarding incongruity and circularity would go as follows: God's charis is completely incongruous with regard to sinful humanity. However, the story does not end here, as God expects some obedience and thus circularity. If divine charis were completely and irreversibly incongruous, no circularity could emerge. While circularity is conceptually different from incongruity, the real world can be so adjusted that they are both possible. An Aristotelian attempts to find a mean which would not violate the basic incongruity but nevertheless allows for some circularity. Therefore, what enables the encounter between the giver and the recipient is not a particular perfection but the moderation of several perfections. Obviously, this systematic argument would need to be accompanied with proper exegetical analysis. 
My second criticism concerns the very concept of incongruity. This concept is not univocal and can, because of historical reasons, contain a variety of different conceptions. When viewed purely abstractly, incongruity is a thin concept. Most things in the world do not fit well together with most other things. We live in a world of incongruities and it is rare to find congruous things, persons and groups. Incongruity is the norm; congruity is the exception.

To be sure, this is not what Protestant theology means with incongruous grace. For modern theologians, incongruity manifests an exception to the worldly rule. Thus, for Barclay, incongruity is connected with gift and grace. If we look at Thomas Aquinas and other Catholic scholastics, however, it is congruity which belongs to the realm of gift and friendship. Thomas holds that because of maximal inequality between God and humans no human can achieve any salvific merit based on worth (ex condigno). However, as God is generous, God can employ congruity which allows to see our worthless efforts in a positive manner (STh II/1 q114 a3r).

Given the gift-like economy of congruity, Thomas even considers that God can employ friendship so that people may help one another in the path of salvation. We cannot give each other any "worthy" merit in that respect, but we may remove obstacles and provide help to each other in the sense of congruity (STh II/1 q114 a6r). If you help me to know Christ, the merit is Christ's, but because of divine congruity you also happen to be there, like a gift for me. In later Catholic theology, merits of congruity can be counted in favor of Christians, although their being congruous derives from God's generosity, not the worth of humans. While justice demands an obligatory reward for merits based on worth, no such reward is required for merits of congruity. God grants the latter bonuses generously, without regard to the worth of the human agent. In addition to the strict economy of worth, God thus employs a gift economy based on congruity.

Due to complex late medieval developments, the Reformers condemn meritum de congruo as a variant of Pelagianism. Luther, Calvin and the Protestant orthodoxy argue that divine grace does not contain the idea of congruity. In other words, God does not consider any additional gift-like rewards related to congruous appearances. Given this, what do the Protestants mean when they speak of incongruous grace? The historical meaning remains restricted to this condemnation and does not yet define the vocabulary of incongruity.

A more elaborated option is to claim that there is a basic discrepancy and incommensurability between God's grace and human standards. Modern Protestant theology has at least since Karl Barth adopted this claim. However, no clear alternative to Thomism emerges from it alone, as Aquinas himself postulates the maximal inequality between God and humans, denying salvific merits based on worth. Therefore, Thomas also adopts a basic theological incongruity in some sense. It can, however, be overcome through God's congruous, gift-like generosity.

John Barclay's own definition of incongruity proceeds very strongly from the concept of worth. The incongruity of a gift "does not take account of prior conditions of worth". It is given "without regard to the worth of the recipient" (both p. 73). The recipients of incongruous grace are "wholly unqualified for divine beneficence". Such event of grace brings "into question every pre-existent classification of worth" (pp. 566-567). The concept of worth is, however, here puzzling, since one is easily misled to think of meritum de condigno as the rejected opposite.

A Reformation scholar like myself is also puzzled by the fact that Barclay's own definitions of incongruity resemble the kind of grace which is assumed to be operative behind 
meritum de congruo, namely, additional beneficence to unworthy recipients. Historically, the merit of congruity was received because of divine generosity. To speak of the gift manifesting an incongruity of grace is therefore somewhat challenging.

Barclay's broader argument concerns the practices of gift-giving in the Greco-Roman world. He argues that the classical tradition of Seneca pays great attention to the worth of the recipients. For Barclay, the gift is congruous when it matches the worth of its recipients. The Pauline gift of grace is thus incongruous when compared to congruous Greco-Roman gifts. We have seen that the Thomist idea of God's donative generosity manifests another variant of congruity. It is not clear, however, whether Barclay's claim of incongruity rejects both the Greco-Roman and the Thomist variants of congruity. It looks that Barclay's incongruity takes over some functions of Thomas's congruity.

However, if one bypasses the Latin traditions, Barclay's point is relatively easy to understand. He proceeds from the post-Barthian discrepancy between human and divine standards. I am ready to agree that Paul's message of grace is something radically new when compared to human standards. It is the term "incongruity" and its historical underpinnings with which I have problems. I am aware that in the particular context of Pauline scholarship this term can illuminate the apostle's alternatives to law and Jewish Christianity and that Barclay's use of it aims to manifest an alternative to the "congruous" Greco-Roman gift practices. As my last point, I mention a problem related to this valuable historical aim.

Regarding the Greco-Roman views, Miriam Griffin argues in her Seneca on Society (2013, pp. 32-36) that Seneca's advice for giving and receiving benefits does not assume an already existing conventional social structure (like friendship or patronage). Rather, the benefits constitute a new, voluntary relationship, often between partners of different status. If Griffin is right, then the Greco-Roman gift practice contains at least some seeds of incongruity. When Seneca's benefits establish new ways of bridging and bonding, while maintaining inequality and distance, they express an incongruous relationship between the giver and the recipient. Seneca's example of Antigonus and the cynic illustrates the constitutive power of the Greco-Roman benefit, moving between incongruity and congruity.

In sum, my second criticism says that it is not sufficient to define the crucial term "incongruity" merely as the opposite to human standards and worth. Given the great sophistication of different gift economies and the principles of congruity operative in them, Barclay's concept remains underdetermined and open to misinterpretation. To rule out this problem, I would like to hear sharper distinctions between different kinds of gift economy. To say that the Pauline gift is incongruous because it "does not take account of prior conditions of worth" does not yet distinguish Pauline gift economy from other historical views of congruity and incongruity. 